\title{
Cancer-Related Pneumopericardium: A Case Report and Literature Review
}

\author{
Samina Hirani ${ }^{a} \quad$ Carol S. Velez Martinez ${ }^{a}$ Shajadi Patan ${ }^{b}$ \\ Mindie Kavanaugh ${ }^{b}$ \\ aDepartment of Internal Medicine, Louisiana State University Health Sciences Center, \\ Shreveport, LA, USA; ' Division of Hematology-Oncology, Feist-Weiller Cancer Center, \\ Louisiana State University Health Sciences Center, Shreveport, LA, USA
}

\section{Keywords}

Pneumopericardium · Cancer - Gastroesophageal junction adenocarcinoma

\begin{abstract}
Pneumopericardium is a relatively rare entity mostly described in the literature as a result of causes such as penetrating/blunt trauma and iatrogenic causes during cardiothoracic procedures. We are presenting a case of pneumopericardium as a complication of progressed gastroesophageal junction tumor along with a literature review of all cancer-related pneumopericardium cases reported in the last decade. We present the case of a 65 -year-old male with a past medical history significant for locally advanced gastroesophageal junction adenocarcinoma who presented to the hospital with complaints of shortness of breath and fever. A chest X-ray showed an intact esophageal stent along with radiolucency around the cardiac silhouette which suggested pneumopericardium. Computed tomography scan of the chest confirmed the presence of pneumopericardium in posterior pericardium with foci of gas above the esophageal stent likely to be communicating with the pericardium. An echocardiogram was obtained which showed no signs of tamponade. Given the advanced nature of the disease we applied a conservative management given that the pneumopericardium was deemed to be small with no tamponade. Goals of care were discussed with the patient and his family and the patient opted for comfort care measures. This case report prompted us to perform an extensive literature review of cancer-related pneumopericardium from 2008 to 2019. We found 11 cases where it was reported secondary to malignancies of different kinds. Our aim is to compile a review for clinicians to view varied presentations and better direct therapy dependent on the individual case and clinical presentation in patients with cancerrelated pneumopericardium. Moreover, although pneumopericardium is rare, it should be considered in differential diagnosis in patients presenting with shortness of breath or chest pain especially with cancers involving the cardiothoracic region.




\section{Introduction}

Pneumopericardium is a relatively rare entity mostly described in the literature as a result of causes such as penetrating/blunt trauma and iatrogenic causes during cardiothoracic procedures and other rare causes such as aspergillosis and diaphragmatic hernia [1,2]. Malignancy has also emerged as a common cause. The last literature review of pneumopericardium focuses on blunt trauma reported in 2008 and iatrogenic causes reported in 2010 [3, 4]. We are presenting a case of pneumopericardium as a complication of progressed gastroesophageal junction tumor along with a literature review of all cancer-related pneumopericardium cases reported in the last 10 years.

\section{Case Report}

We present a case of a 65-year-old male with a past medical history significant for locally advanced gastroesophageal junction adenocarcinoma treated with neoadjuvant concurrent chemoradiation therapy. The patient was found to have a recurrence of cancer within a year, with metastasis to the lung. He was on palliative carboplatin and paclitaxel therapy when he presented to the emergency department complaining of shortness of breath and a fever of $103^{\circ} \mathrm{F}$ at home. On initial examination, the patient was found to have diminished air entry on the right inferior lung field. The cardiac examination was remarkable for irregular rhythm with normal S1 and S2 and jugular venous distension greater than $10 \mathrm{~cm}$. Initial labs showed pancytopenia. Chest radiography (CXR) showed an intact esophageal stent along with radiolucency around the cardiac silhouette suggesting pneumopericardium (Fig. 1). Computed tomography (CT) scan chest confirmed the presence of pneumopericardium in posterior pericardium (Fig. 2a) with foci of gas above the esophageal stent likely communicating with the pericardium (Fig. 2b). A following echocardiogram (echo) revealed an echoic dense space at the basal part of the heart consistent with the pneumopericardium without any signs of tamponade. Cardiothoracic surgery and gastrointestinal services were consulted for surgical and/or endoscopic evaluation. We applied a conservative management since the hemody-

Fig. 1. Upright CXR: arrows indicate radiolucent rim surrounding the cardiac silhouette.

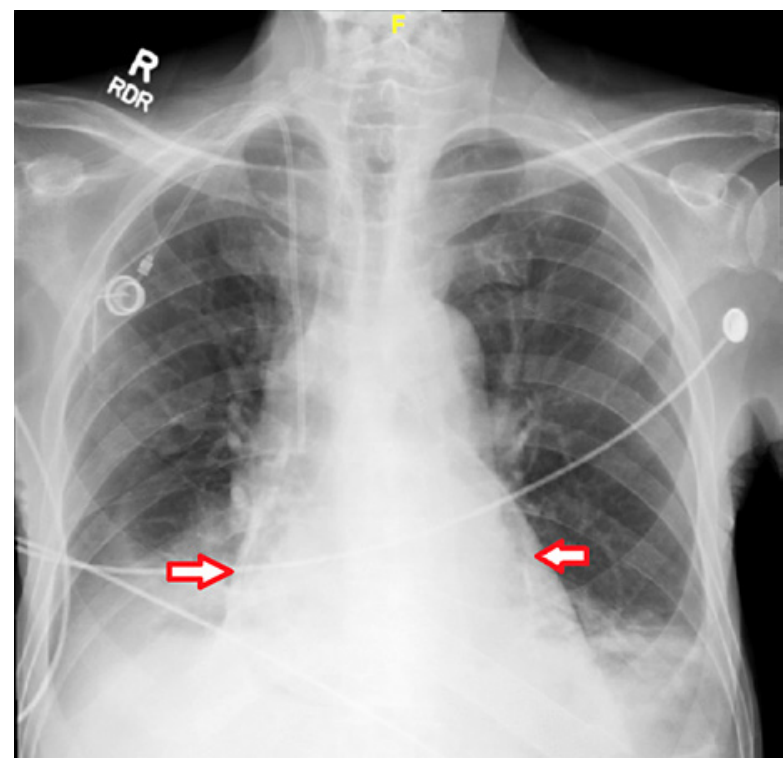


namics improved and there was no sign of tamponade. Due to the advanced nature of the disease and poor performance score, goals of care were discussed with the patient and his family; thepatient opted for comfort care measures.

\section{Discussion}

Pneumopericardium, though rare, has been described in the literature since 1884 [3]. Since then numerous causes have emerged with traumatic causes being the most common ones reported in the literature. A review from 1971 emphasized cancer as an emerging cause of pneumopericardium [5]. Here we are reviewing cancer-related pneumopericardium in the past 10 years [5].

We identified 11 cases reported in the last 10 years with cancer-related pneumopericardium. Key findings with regard to chief complaints, malignancy, imaging, and interventions are summarized in Table 1 . Demographically 10/11 cases, including our case, were males in the age range of 50-81 years. The only notable female case reported by Rao et al. [6] in 2013 is of a 6-year-old girl with acute lymphoblastic leukemia. Most cases revolve around solid malignancies located in either the lung or esophagus, with the exception of 2 cases, one related to acute lymphoblastic leukemia and another to NK/T-cell lymphoma. Similar to our case, dyspnea was the most common presenting symptom along with chest pain [7-9]. Other common presentation symptoms included cough, fever, weight loss, and hemoptysis [9-11].

Physical examination provides important clues for diagnosis. Commonly reported physical exam findings included distant heart sounds [11,12]. Classic findings such as Haman's crunch and subcutaneous emphysema are seen with pneumomediastinum; however, they can coexist with pneumopericardium and hence clinicians should keep an eye out for them as they can point toward the diagnosis. Assessment of hemodynamic stability is imperative during initial evaluation. Any signs of impaired ventricular filling could pinpoint to cardiac tamponade and require immediate intervention.

The diagnosis of pneumopericardium can be achieved with imaging modalities such as a conventional chest X-ray, CT or echocardiogram. Radiographic findings are usually described as a radiolucent halo that covers the cardiac silhouette [12]. A few classic signs described in the literature include small heart signs where a smaller heart is seen on CXR and which consequently return to normal size postintervention [13]. Other common signs included continuous hemidiaphragm signs which are seen essentially on the lateral radiograph in which air in the pericardium highlights the normally obscured part of heart [14]. It is also important to distin-
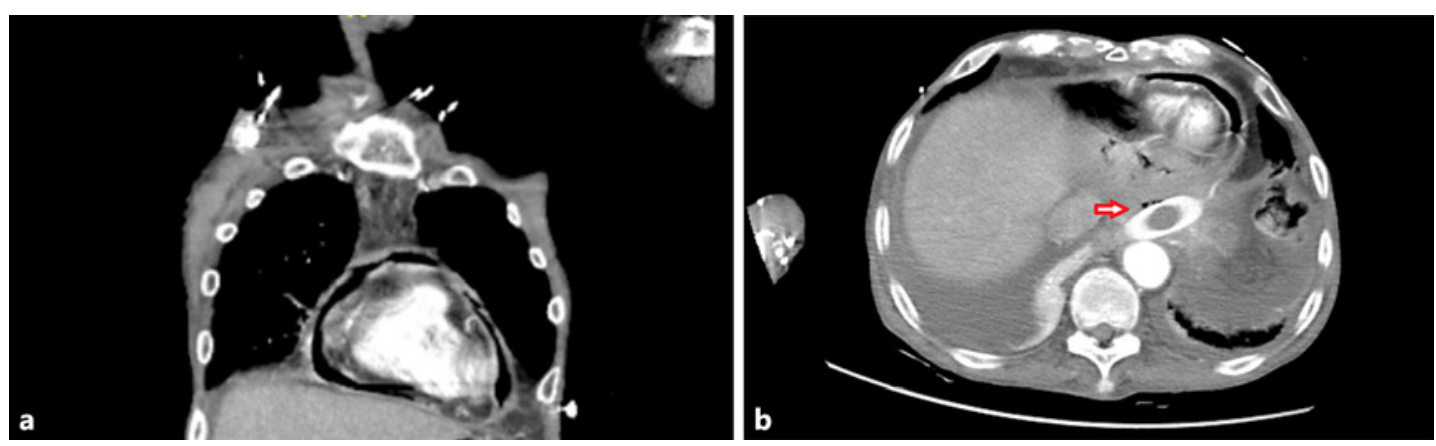

Fig. 2. a Chest CT coronal view of pneumopericardium. b Axial chest CT: red arrows identify punctate foci of gas, seen anterior to the esophageal stent, are in intimate contact with the posterior pericardium, and may represent the site of communication. 
Table 1. Summary of the literature review

\begin{tabular}{|c|c|c|c|c|c|c|c|}
\hline Authors & Age & Sex & Symptoms & Cancer & Fistula & Approach & Survival \\
\hline $\begin{array}{l}2019 \\
\text { Mandal } \\
\text { et al. [18] }\end{array}$ & 81 & M & Dyspnea, cough & $\begin{array}{l}\text { SCC } \\
\text { esophagus }\end{array}$ & Esophagopericardial & $\begin{array}{l}\text { Asymptomatic pneumopericardium, } \\
\text { managed conservatively }\end{array}$ & 10 days \\
\hline $\begin{array}{l}2018 \\
\text { Fournel } \\
\text { et al. [17] }\end{array}$ & 84 & M & Cardiogenic shock & Esophageal & Esophagopericardial & $\begin{array}{l}\text { Pericardiocentesis and closed drainage } \\
\text { with echo guidance was performed to } \\
\text { relive the symptoms and later endoscopic } \\
\text { stent was placed to block the fistula }\end{array}$ & 4 days \\
\hline $\begin{array}{l}\text { Lages } \\
\text { et al. [9] }\end{array}$ & 66 & M & Dyspnea, chest pain & SCC lung & Bronchopericardial & $\begin{array}{l}\text { Patient had low functional status, no } \\
\text { intervention was pursued }\end{array}$ & 3 weeks \\
\hline $\begin{array}{l}2017 \\
\text { Liao } \\
\text { et al. [16] }\end{array}$ & 53 & M & $\begin{array}{l}\text { Dyspnea, fever, back } \\
\text { pain (thoracic) }\end{array}$ & SCC lung & Esophagopericardial & $\begin{array}{l}\text { Pericardiocentesis and endoscopy-guided } \\
\text { stent placement to close off the fistula }\end{array}$ & NA \\
\hline $\begin{array}{l}2016 \\
\text { Wang } \\
\text { et al. [8] }\end{array}$ & 53 & M & Dyspnea, chest pain & Lung & $\begin{array}{l}\text { Esophagopericardial } \\
\text { secondary to radiation- } \\
\text { induced esophagitis }\end{array}$ & $\begin{array}{l}\text { Pericardiocentesis and endoscopy- } \\
\text { guided stent placement to close off the } \\
\text { fistula }\end{array}$ & NA \\
\hline $\begin{array}{l}\text { Kubisa } \\
\text { et al. [11] }\end{array}$ & 42 & M & $\begin{array}{l}\text { Fever, cough, weight } \\
\text { loss, presence of mass } \\
\text { left axillary region }\end{array}$ & NSCLC & $\begin{array}{l}\text { Bronchopericardial and } \\
\text { pleural }\end{array}$ & $\begin{array}{l}\text { Palliative treatment with } \\
\text { videothoracoscopic fenestration of the } \\
\text { pericardium and pleural drainage }\end{array}$ & NA \\
\hline $\begin{array}{l}\text { Al-Taweel } \\
\text { et al. [10] }\end{array}$ & 56 & M & Hemoptysis, cough & SCC Lung & $\begin{array}{l}\text { Direct invasion into the } \\
\text { left atrium }\end{array}$ & $\begin{array}{l}\text { Underwent VATS surgery with pericardial } \\
\text { window }\end{array}$ & $>6$ months \\
\hline $\begin{array}{l}2013 \\
\text { Sener } \\
\text { et al. [12] }\end{array}$ & 51 & M & Fever, cough & $\begin{array}{l}\mathrm{T} / \mathrm{NK} \text { cell } \\
\text { lymphoma }\end{array}$ & Gastropericardial fistula & $\begin{array}{l}\text { Underwent pericardial drainage with } \\
\text { tube placement and referred to CTS }\end{array}$ & $\begin{array}{l}\text { Death post- } \\
\text { operatively due to } \\
\text { septic shock }\end{array}$ \\
\hline $\begin{array}{l}\text { Laxman Rao } \\
\text { et al. [6] }\end{array}$ & 6 & F & Dyspnea, fever & ALL & Unknown & Pericardiocentesis & NA \\
\hline $\begin{array}{l}2011 \\
\text { Kasama } \\
\text { et al. [19] }\end{array}$ & 64 & $\mathrm{M}$ & Dysphagia & $\begin{array}{l}\text { SCC } \\
\text { esophagus }\end{array}$ & Esophagopericardial & $\begin{array}{l}\text { Exploratory laparatomy with } \\
\text { pericardectomy, later underwent EGD } \\
\text { identifying fistula }\end{array}$ & NA \\
\hline $\begin{array}{l}2008 \\
\text { Imai } \\
\text { et al. [7] }\end{array}$ & 77 & M & Dyspnea & SCC lung & $\begin{array}{l}\text { Pleural space- } \\
\text { pericardum }\end{array}$ & $\begin{array}{l}\text { Underwent pericardiocentesis with } \\
\text { drainage }\end{array}$ & NA \\
\hline
\end{tabular}

M, male; F, female; SCC, squamous cell carcinoma; NSCLC, non-squamous cell lung cancer; ALL, acute lymphoblastic leukemia; NA, not available; EGD, esophagogastroduodenoscopy.

guish pneumopericardium from pneumomediastinum as the latter is more common. If the CXR includes air around the heart extending beyond the left ventricle and right atrium and envelopes the aortic arch and superior vena cava above the azygous vein or the distal left pulmonary artery, this means it is outside the limits of the pericardium and leads to a diagnosis of pneumomediastinum [15]. Commonly, CXR was followed by a CT scan of the chest for confirmation. The biggest advantage of CT is defining the extent of air present in the pericardial sac, identifying new or recurrent malignancies and the presence of communication between the airway and gastrointestinal system resulting in the pneumopericardium. Identifying the fistula can assist with the management. Two similar cases described by Liao et al. [16] and Wang et al. [8] presented with an esophageal-pericardial fistula identified by CT scan. Both were treated by placing a stent and then the pneumopericardium resolved. Echocardiography also serves multiple functions when evaluating pneumopericardium. Echo can assess left ventricular function and measure the degree of cardiac compromise. Key findings summarized by Liao et al. [16] included the absence of an image when there is a large amount of air in the pericardium which blunts the image from the probe; an air gap sign where the 
image disappears when the heart contracts during systole; a swirling bubble sign where multiple echogenic spots are identified in pericardial sac; and rectilinear echoes where multiple bright echoes pile up to form a rectilinear line which corresponds to the air-fluid level [16]. Most importantly, echocardiography allows for guided pericardiocentesis.

Treatment was dependent on the hemodynamic compromise and underlying cause. Gold standard management is pericardiocentesis, usually guided by echography. The case presented by Fournel et al. [17] described a male presenting with cardiogenic shock requiring CT-guided pericardiocentesis. Imai et al. [7] described a case of pneumothorax with pneumopericardium after lobectomy due to a connection between pleura and pericardium due to a tear in the pericardium. A simple chest tube provided resolution of both the pneumothorax and pneumopericardium [7]. Other treatment focused on the location of the fistula. Endoscopy played an important role, such as used in the case of esophageal cancer stent implantation to block of the esophageal pericardial fistula [16]. It was important to watch for the development or presence of cardiac tamponade, in which case an urgent pericardiocentesis or pericardial window is warranted $[6,8,10-12]$. Stable, asymptomatic patients can also be managed conservatively. It is fundamental to include the prognosis of the disease and functional status, when generating a management plan. Our case presents pneumopericardium in a patient with advanced gastroesophageal junction tumor with no concerns for tamponade and hemodynamic stability that was treated appropriately with conservative measures and palliative treatment like other cases with advanced cancers and poor performance status $[9,18]$.

\section{Conclusion}

Although pneumopericardium is rare, it should be considered in the differential diagnosis in patients presenting with shortness of breath or chest pain especially with cancers involving the cardiothoracic or gastric region. Our aim was to compile a review for clinicians to view varied presentations and different therapeutic approaches specific to each case and clinical presentation. Physical examination plays an important role in assessing hemodynamic stability and the need for emergent intervention. Many imaging modalities encompass classic findings suggestive of the diagnosis of pneumopericardium. CT was commonly used for confirmation of diagnosis and identification of a fistula. Pericardiocentesis remains the gold standard for intervention, which can be guided by CT or echography. For fistula communicating with the pericardium, endoscopy with a stent would resolve the pneumopericardium. Moreover, each presenting case should take into consideration the functional status and prognosis of the patient as a more conservative and palliative management could be the main approach.

\section{Statement of Ethics}

The study complied with guidelines for human studies and informed consent was obtained from the patient's next of kin.

\section{Disclosure Statement}

We certify that the authors listed here have no affiliations with or involvement in any organizations and/or any financial interests. 
Hirani et al.: Cancer-Related Pneumopericardium

\section{Funding Sources}

None.

\section{Author Contributions}

S. Hirani conceived the design, reviewed the medical records, interpreted data, reviewed literature and wrote the manuscript. C. Martinez reviewed the literature and wrote the manuscript. S. Patan and M. Kavanaugh verified the work, supervised the study, and critically revised the manuscript.

\section{References}

1 van Ede AE, Meis JF, Koot RA, Heystraten FM, de Pauw BE. Pneumopericardium complicating invasive pulmonary aspergillosis: case report and review. Infection. 1994 Mar-Apr;22(2):102-5.

2 Grandhi TM, Rawlings D, Morran CG. Gastropericardial fistula: a case report and review of literature. Emerg Med J. 2004 Sep;21(5):644-5.

3 Bricheteau M. Observation d'hydropneumopéricarde accompagné d'un bruit de fluctuation perceptible a l'oreille [in French]. Arch Gen Med. 1844;4:334-9.

4 Visser F, Heine M, Levin AI, Coetzee AR. Pneumopericardium: two case reports and a review. South Afr J Anaesth Analgesia. 2008;41-5.

5 Russell DA, Boland MJ, Foster JB, Fletcher JA, Bass EJ, Thompson TA. Pneumopyopericardium complicating gastric cancer. J Miss State Med Assoc. 1984 Oct;25(10):264-6.

6 Rao KL, Imamuddin S, Kumar AP. Isolated tension pneumopericardium in a case of acute lymphoblastic leukemia. Indian Heart J. 2013 Dec;65(6):705-6.

7 Imai A, Ishikawa S, Nakamura R, Goto Y, Sakai M, Onizuka M, et al. Pneumopericardium 3 years after lung cancer surgery. Ann Thorac Surg. 2008 Feb;85(2):664.

8 Wang S, Peng D, Tang J. Oesophageal fistula-related pneumopericardium secondary to radiochemotherapy. Eur Heart J. 2017 Aug 21;38(32):2511.

9 Lages J, Oliveira CC, Lacerda C. Pneumopericardium due to bronchopericardial fistula in a patient with lung cancer. BMJ Case Rep. 2018 Sep;28;2018.

10 Al-Taweel A, Ayub A, Huang CY, Rehmani S, Al-Ayoubi A, Bhora FY. Pneumopericardium leading to cardiac tamponade in a patient with lung cancer. Thorac Cardiovasc Surg Rep. 2016 Dec;5(1):13-5.

11 Kubisa A, Lesińska A, Dec P, Szewczak-Głodek M, Kochanowski L, Kubisa B, et al. Pneumopericardium as a non-small-cell lung carcinoma complication. Kardiochir Torakochirurgia Pol. 2016;3:257-9.

12 Sener YZ, Babacan T, Sarica MA, Turkbeyler IH. A patient with pneumopericardium secondary to extranodal T-cell lymphoma. BMJ Case Rep. 2013 Nov 12;2013.

13 Mirvis SE, Indeck M, Schorr RM, Diaconis JN. Posttraumatic tension pneumopericardium: the "small heart" sign. Radiology. 1986 Mar;158(3):663-9.

14 Brander L, Ramsay D, Dreier D, Peter M, Graeni R. Continuous left hemidiaphragm sign revisited: a case of spontaneous pneumopericardium and literature review. Heart. 2002 Oct;88(4):e5.

15 Bejvan SM, Godwin JD. Pneumomediastinum: old signs and new signs. AJR Am J Roentgenol. 1996 May;166(5): 1041-8.

16 Liao HQ, Zhou D, Shang QL, Shi YF, Zhang M. Pneumopericardium as a rare complication after esophagopericardial fistula. Echocardiography. 2017 May;34(5):779-81.

17 Fournel L, Decembrino F, Paci M, Lococo F. Massive pneumopericardium as onset symptom of fistulizing oesophageal cancer. Eur J Cardiothorac Surg. 2018 Jul;54(1):194.

18 Mandal AKJ, Htet ZY, Missouris CG. Pneumopericardium complicating esophageal cancer. ACG Case Rep J. 2019 Feb;6(1):1-2.

19 Kasama K, Rino Y, Murakami H, Suzuki S, Isomatsu Y, Masuda M. Pneumopericardium from esophageal-pericardial fistula due to cancer recurrence. Asian Cardiovasc Thorac Ann. 2011;19(6):444. 